\title{
Ter equilíbrio, para dar equilíbrio
}

\author{
Fátima Niemeyer da Rocha.
}

ABDALLA, Ively Guimarães. Ter equilíbrio, para dar equilíbrio. Profissão psicólogo? Um estudo sobre as representações sociais dos alunos de um curso de psicologia. São Paulo: Arte e Ciência, 1998. Coleção Estudos Acadêmicos.

A autora é professora do curso de graduação em Psicologia da UNIP, instituição particular de ensino superior localizada na cidade de São Paulo, onde desenvolveu a pesquisa que serve de referência à obra. $\mathrm{O}$ material aqui resenhado consta de uma pesquisa sobre como o aluno do curso de psicologia constrói, no cotidiano de sua atividade discente, a sua identidade como profissional. Trata-se de uma investigação a respeito das representações sociais que os alunos de psicologia elaboram sobre a carreira/profissão e o ser psicólogo, com o objetivo de acompanhar e entender o processo de construção da sua identidade profissional, no decorrer de sua formação, e como a representação social se integra na sua prática.

No primeiro capítulo, a autora aborda os conceitos de representação social, de identidade e de profissional. Analisa quem é o psicólogo e sua função e mostra que o aluno quando procura o curso de Psicologia, seja qual for o motivo da escolha, traz uma representação profissional moldada socialmente, com base no senso comum. No curso o aluno encontra um profissional, psicólogo, que assume o papel de professor e se torna um modelo de profissional. Como a vivência na universidade vai trazer aos alunos muitos professores que se identificam com diferentes teorias/ abordagens da Psicologia e têm uma forma peculiar de representação social do cotidiano do psicólogo, cada professor vai mostrar aos alunos um modelo de profissional. Como resultado, cada aluno vai identificarse com o modelo de profissional que for mais próximo de sua história pessoal. Durante a vida universitária, o aluno de Psicologia constrói sua identidade através das relações sociais que estabelece e pela forma como assimila o real. Ao apropriar-se da realidade o aluno está construindo uma representação social, mediadora da relação homem-mundo, que é também elaborada nas interações sociais e se manifesta no psiquismo individual, podendo ser observada e analisada através da linguagem do indivíduo, pois está corporificada no seu discurso. Por esse motivo, a autora procura acessar as representações dos alunos por meio de informações obtidas através de entrevistas e questionários, isto é, através da sua expressão verbal. Parte da hipótese de que as pesquisas e os aspectos de teorias científicas que o aluno aprende durante sua escolaridade, as ideias, as imagens veiculadas pelos meios de comunicação e a convivência com os professores na universidade podem contribuir para a forma como elabora as representações sociais do ser psicólogo e da Psicologia, que vão influenciar a construção de sua identidade.

No segundo capítulo, é apresentado um breve histórico da trajetória da Psicologia brasileira, com a análise de seu desenvolvimento através da apreciação de obras consagradas da nossa literatura, com o intuito de compreender os fatores que influenciaram a construção do perfil do psicólogo como profissional em nosso país. A história da Psicologia no Brasil é dividida em quatro períodos distintos: no primeiro período, da Psicologia pré-institucional, sob o domínio da Medicina, numa vertente biologizante, o perfil do psicólogo se assemelha ao do médico que tem a missão de curar os dementes; a Psicologia encontra-se num campo indefinido da religião, da filosofia, da ética, da pedagogia e da medicina. No segundo período, da institucionalização, com o surgimento da psicologia experimental, a psicologia apresenta um novo perfil, abandonando os pressupostos da Medicina para encontrar os seus próprios pressupostos; os laboratórios tornam-se os lugares da certeza científica, da constituição de leis seguras para as teorias psicológicas; observa-se a grande influência das teorias darwinistas e positivistas, os estudos aprofundados sobre a personalidade, a cognição, a afetividade e os problemas neuropsicológicos, além da entrada da Psicologia no campo da educação. No

Universidade Severino Sombra, Pró-Reitoria de Ciências da Saúde e Humanas, Vassouras-RJ, Brasil. 
terceiro período, o da Psicologia institucionalizada na universidade, há o desenvolvimento de pesquisas nos laboratórios acadêmicos, passando a ser disciplina obrigatória de ensino superior de cursos como Filosofia, Ciências Sociais e Pedagogia, entre outros. E no quarto período, da conquista de novos espaços e consolidação da Psicologia brasileira, ocorre a criação dos cursos de bacharelado e licenciatura em Psicologia e a regulamentação da profissão de psicólogo, em 1962, com a aceitação e o respeito da opinião pública pela função de psicólogo como distinta da atuação médica ou pedagógica.

No terceiro capítulo, Abdalla apresenta e o cenário da realização do estudo: o campus de uma universidade particular da cidade de São Paulo, cujo alunado é oriundo da classe média. Descreve a pesquisa realizada a partir de uma abordagem qualitativa, para o conhecimento das representações dos alunos durante o transcorrer do curso de Psicologia. Procurou três tipos de alunos: os que somente cursavam Psicologia; os que cursavam Psicologia e também faziam monitoria durante o curso; e os que cursavam Psicologia e participavam de atividades no Centro Acadêmico. Esclarecendo que, na determinação do tamanho da amostra, não houve preocupação com a representatividade estatística, entrevistou os alunos interessados em colaborar com a pesquisa, que procuraram espontaneamente a entrevistadora. Foram privilegiados os discursos dos próprios alunos como fonte de informações para análise das suas representações sobre a futura profissão, sobre sua prática e sobre si mesmos. A coleta de informações foi feita através de entrevistas semi-estruturadas, cujo roteiro englobava questões sobre a história da escolha da profissão, o conceito de Psicologia, o conceito de psicólogo, a atuação profissional do psicólogo na prática social, as influências positivas e negativas do curso de Psicologia em relação às representações sociais que traziam da Psicologia e do ser psicólogo, as influências positivas e negativas da mídia e da sociedade em geral em relação às representações sociais que traziam da Psicologia e do ser psicólogo e a representação social sobre si mesmos enquanto futuros profissionais.

No quarto capítulo, a autora analisa a fala de cada um dos entrevistados. Considera que a representação social que o aluno do primeiro ano faz é fruto do impacto da entrada no curso; a representação social do aluno do terceiro ano é resultado das experiências vividas no decorrer do curso; e a representação social do aluno do quinto ano é uma consequência das anteriores.

No quinto capítulo, Abdalla apresenta uma análise mais global das entrevistas, onde constata que a maioria dos alunos entrevistados entra no curso de Psicologia com representações do modelo de Psicologia vinculado à Medicina, ligadas a concepção de 'doença' e 'cura'. Não conseguem chegar à representação da real função social da profissão de psicólogo, sendo visto apenas como psicólogo clínico, atuando somente em consultório e com pessoas de uma camada social mais elevada da população. Aponta para o fato das universidades desenvolverem planos de pesquisa e formação de psicólogos sem a preocupação de preparálos para a atuação profissional. Em decorrência, as representações profissionais estariam relacionadas mais às cristalizações históricas de estereótipos, do que a práticas profissionais efetivas. Por outro lado, dado o dinamismo dasrepresentações sociais quese transformam de acordo com as relações estabelecidas pelo sujeito, as entrevistas confirmam que as representações iniciais dos alunos sofrem mudanças quando: entram em contato com novas informações obtidas no curso através dos professores, realizam pesquisas sobre o ser psicólogo e participam de estágios. Porém nem toda representação social sobre o ser psicólogo é transformada e, em alguns casos, o impacto do curso não se revela suficientemente forte na sua ação transformadora. Isto ocorre mais entre os alunos de primeiro ano, que demonstram não compreenderem a amplitude da profissão e suas relações com outras áreas do conhecimento para o desempenho de sua função social. Também aparece a opção pela profissão como meio de preencher o 'vazio' afetivo e de ressignificar a vida pessoal. Durante o curso, entre alunos do terceiro ano, aparece a percepção da função social da profissão e a amplitude do campo da psicologia, a partir das relações com os professores e as informações obtidas em pesquisas. Percebe-se um forte interesse em buscar novas informações, garantindo a criação de uma identidade mais próxima da realidade profissional. Os alunos do quinto ano apresentam uma mudança efetiva na representação social da atuação do psicólogo a partir das experiências vivenciadas no curso. Nas relações com os professores perceberam as possibilidades de trabalho fora do campo do consultório. A autora conclui ser muito importante o papel do professor na formação da identidade profissional do aluno de psicologia. O professor, nas relações educacionais cotidianas, traz para os alunos outras informações e valores que se confrontam com as representações sociais que os alunos trazem de suas experiências passadas. Desta forma, cabe ao professor estabelecer este vínculo com o aluno para a construção da sua identidade profissional.

Nas considerações finais, ao relacionar a história de vida de cada um dos alunos entrevistados com suas representações sociais do psicólogo, a autora percebe que as representações que, num primeiro momento, são expressas individualmente, foram construídas socialmente. Há um movimento de fases distintas, que vão de uma identidade profissional construída a partir de representações sociais feitas a partir de estereótipos sobre a psicologia e o ser psicólogo, para uma identidade profissional alicerçada em uma tomada de consciência sobre a importância da psicologia na sociedade, a função social do psicólogo nesta sociedade e a pluralidade de 
opções de atuação desse profissional. Essa consciência se dá do meio para o final do curso, quando o aluno está de posse de novas informações, de novas práticas sociais e profissionais. Daí a importância do professor e da estruturação do currículo do curso de Psicologia.

Pela atualidade do tema e pelo posicionamento crítico da autora em relação ao papel do professor de Psicologia na construção da representação social da profissão de psicólogo, o livro de Ively Guimarães Abdalla é um importante material de leitura para todos os envolvidos com a área de ensino da Psicologia. 